\title{
PENGARUH STIMULANSIA ETHREL 10 PA TERHADAP PRODUKSI LATEKS TANAMAN KARET ( Hevea brasilliensis ) PADA KLON RRIC 100 DI PERKEBUNAN KALISANEN
}

\section{EFFECT STIMULANT ETHREL 10 PA LATEX PLANT PRODUCTION OF RUBBER (Hevea brasilliensis) IN THE CLONES RRIC 100 PLANTATION KALISANEN}

\author{
${ }^{1}$ Danis Eko Prasetyo, ${ }^{2}$ Dian Hartatie dan ${ }^{3}$ Ujang Setyoko \\ 1,2,3Program Studi Produksi Tanaman Perkebunan Jurusan Produksi Pertanian Politeknik Negeri Jember \\ Jalan Mastrip Kotak Pos 164 Jember
}

\begin{abstract}
Abstrak
Tanaman karet (Hevea brasiliensis Muell.) merupakan tanaman perkebunan yang penting di Indonesia, karena merupakan salah satu produk non migas yang menjadi sumber pemasukan devisa negara dalam jumlah yang besar. Hasil utama tanaman karet adalah getah (lateks). Lateks tersebut berperan besar sebagai bahan baku, mulai dari peralatan transportasi, medis, dan alat-alat rumah tangga. Stimulant adalah suatu campuran yang terdiri dari minyak nabati (misalnya minyak kelapa sawit) dengan gemuk alami (disebut carrier stimulant) dan hormone (missal 2,4-D)atau bahan aktif lainnya misalnya Ethefon. Ethrel 10 PA adalah plant growth regulator buatan Bayer yang bisa digunakan pada perkebunan karet untuk menutup luka bidang sadap. Ethilen yang dihasilkan akan menekan jumlah hormon auxin yang dapat merangsang tumbuhnya akar di bekas luka. Chi kuadrat adalah teknik analisis satistik untuk mengetahui signifikansi perbedaan antara proporsi (dan atau probabilitas) subjek atau objek penelitian yang datanya telah terkatagorikan. Dasar pijakan analisis dengan chi kuadrat adalah jumlah frekuensi yang ada. Analisis menggunakan uji Chi - Kuadrat menunjukan hasil yang berbeda nyata. Hal ini menjelaskan bahwa pemberian stimulant pada tanaman karet berpengaruh baik pada produksi yang dihasilkan.
\end{abstract}

Kata kunci: Ethrel, Analisis Chi-Kuadrat, Karet, Produksi lateks

\begin{abstract}
Rubber tree (Hevea brasiliensis Muell.) Is an important plantation crops in Indonesia, because it is one of the non-oil products are a source of foreign exchange income in large quantities. The main result is the rubber plant sap (latex). The latex was an important raw material, ranging from transportation equipment, medical, and household appliances. Stimulant is a mixture consisting of vegetable oils (eg palm oil) with a natural fat (called the carrier stimulant) and hormones (eg, 2,4-D) or other active ingredients, for example Ethefon. Ethrel $10 \mathrm{PA}$ is an artificial plant growth regulators that Bayer can be used on rubber tapping to close the wound field. Ethilen generated will suppress the hormone auxin to stimulate the growth of roots in the scar. Chi square is a statistic analysis techniques to determine the significance of the difference between the proportion (or probability) the subject or object of study for which data has been terkatagorikan. Basic footing with chi square analysis is the number of frequencies available. The analysis using Chi - Square showed significantly different results. It is clear that the provision of the rubber plant stimulant good influence on the resulting production.
\end{abstract}

Key words: Ethrel, Chi-Square Analysis, Rubber, Latex Production 
Danis Eko Prasetyo, Dian Hartatie dan Ujang Setyoko, Pengaruh Stimulansia Ethrel 10 PA Terhadap Produksi Lateks Tanaman Karet (Hevea brasilliensis) Pada Klon RRIC 100 Di Perkebunan Kalisanen

\section{PENDAHULUAN}

\subsection{Latar Belakang}

Penurunan jumlah produksi dapat terjadi salah satunya karena penurunan luas lahan yang terjadi pada tahun tersebut. Usaha peningkatan produksi lateks dewasa ini dilakukan melalui berbagai usaha, antara lain melaksanakan teknis budidaya yang baik seperti menanam klon unggul, pemupukan dengan dosis yang tepat dan teratur, system penanaman dan pemeliharaan yang baik, dan lain sebagainya. Dalam dua - tiga dasa warsa terakhir ini telah dikembangkan pula penggunaan stimulant. Penggunaan stimulant dewasa ini sudah umum pada perkebunan - perkebunan milik PTP dan perkebunan besar swasta. Pada perkebunan rakyat penggunaan stimulant mungkin belum bias karena adanya kekurangtahuan terhadap stimulant tersebut. Namun dimasa depan kiranya hal ini tidak akan menjadi masalah lagi. Karena program penyuluhan pada perkebunan - perkebunan rakyat semakin intensif (Setyamidjaja 1993).

Pemberian stimulant bertujuan untuk meningkatkan produksi lateks. Pemberian stimulant etrell 10PA ini bertujuan untuk memberi pengetahuan baru yang positif pada petani karet dalam menghasilkan produksi lateks. Ethrel 10PA merupakan zat pengatur tumbuh (ZPT) tanaman yang dapat digunakan untuk merangsang keluarnya lateks pada tanaman karet

Berdasarkan uraian latar belakang diatas maka rumusaan masalah penelitian ini adalah apakah pemberian stimulant ethrel berpengaruh terhadap produksi lateks pada tanaman karet klon RRIC 100.

\subsection{Tujuan}

Berdasarkan uraian latar belakang dan rumusan masalah di atas, maka tujuan penelitian ini adalah menguji pengaruh pemberian stimulant ethrel terhadap perkembangan hasil produksi lateks pada tanaman karet klon RRIC 100.

\subsection{Manfaat}

Manfaat hasil dari penelitian ini, adalah :Memberi pengetahuan baru kepada petani karet tentang manfaat stimulant ethrel 10 PA terhadap perkembangan hasil produksi lateks.

a. Memberi pengetahuan kepada para petani karet dalam penggunaan stimulant ethrel dalam meningkatan hasil produksi.

\section{Tinjauan Pustaka \\ Botani Karet RRIC}

Menurut Setyamidjaja (1993) dan Balai Penelitian Sungei Putih (2007) ciri-ciri tanaman RRIC 100 adalah sebagai berikut :

Batang: jagur, tegak lurus, silindris;
Kulit batang

Mata

Payung

Tangkai daun

Anak tangkai daun

Helai daun

Warna lateks : warna coklat, celah-
celah merupakan alur
panjang dan sempit
kadang-kadang terputus-
putus, lentisel sedikit dan
halus; : letaknya rata dan bekas tangkai daun besar dan agak bergerombol;

: bentuk setengah bulatan sampai bentuk kerucut terpotong, besar, agak terbuka, tangkai-tangkai daun agak rapat, jarak antar payung sedang;

: bentuknya lurus sampai sedikit cembung, panjang, arahnya mendatar sampai sedikit terkulai, pangkal tangkai daun besar dan dibagian atasnya rata;

: bentuknya lurus sampai agak cembung, panjang, arahnya sedikit menjungkat, membentuk sudut $\pm 60^{\circ}$;

: warna hijau kekuningkuningan, berkilau, agak kaku, bentuk oval panjang, panjang $3 \mathrm{x}$ lebar, pinggir daun agak bergelombang tak teratur, ujung daun lebar melengkung dengan ekor daun agak panjang, penampang melintar datar sampai sedikit berbentuk huruf $\mathrm{V}$, penampang memanjang agak cembung, letak daun landai, antar daun terpisah dan daun tengah terletak dalam satu bidang dengan daun pinggir;

: putih

\section{Stimulan Ethrel}

Ethrel 10 PA adalah plant growth regulator buatan Bayer yang bisa digunakan pada perkebunan karet untuk menutup luka bidang sadap. Ethilen yang dihasilkan akan menekan jumlah hormon auxin yang dapat merangsang tumbuhnya akar di bekas luka. Dengan mekanisme seperti ini maka pembentukan kalus pada luka bidang sadap akan terhambat dan luka akan menutup dengan baik. Ethrel bekerja dengan cara sistemik. Sesaat setelah masuk ke dalam lapisan tanaman melalui penyemprotan, Ethrel akan mengalami proses 
Danis Eko Prasetyo, Dian Hartatie dan Ujang Setyoko, Pengaruh Stimulansia Ethrel 10 PA Terhadap Produksi Lateks Tanaman Karet (Hevea brasilliensis) Pada Klon RRIC 100 Di Perkebunan Kalisanen

dekomposasi menjadi ethilen, yang mempengaruhi proses pematangan buah.

\section{METODOLOGI}

\subsection{Waktu dan Tempat}

Penelitian ini dilaksanakan di kebun karet PTPN XII Kalisanen afdeling Mei 2015

\subsection{Alat dan Bahan}

Bahan Penelitian: Bahan yang digunakan adalah stimulant ethrel 10PA,

tanaman karet (TM) yang berumur 10-15 tahun, asam semut $1 \%$.

Alat Penelitian : Alat yang digunakan adalah mangkuk lateks, cincin

mangkuk, pisau sadap, talang sadap, bold (timba besar), kuas, timbangan, mesin penggiling.

\subsection{Metode Penelitian}

Menurut (Soepeno 2002) Chi kuadrat adalah teknik analisis satistik untuk mengetahui signifikansi perbedaan antara proporsi (dan atau probabilitas) subjek atau objek penelitian yang datanya telah terkatagorikan. Dasar pijakan analisis dengan chi kuadrat adalah jumlah frekuensi yang ada. Di dalam teknik chi kuadrat terdapat dua kelompok frekuensi, yaitu frekuensi hasil pengamatan (hasil observasi) dan frekuensi yang diharapkan. Frekuensi pengamatan merupakan data yang diperoleh dari objek penelitian yang disingkat $\mathrm{f}_{\mathrm{o}}$, sedangkan frekuiensi yang diharapkan (expected) adalah frekuensi sebagai pembanding, disingkat dengan $\mathrm{f}_{\mathrm{e}}$. Berikut rumus dari Chi kuadrat :

$X^{2}=\frac{\Sigma\left(f_{o}-f_{e}\right)^{2}}{f_{e}}$

Keterangan :

$\mathrm{X}^{2}$

$f_{0}$

: Chi kuadrat

sampel penelitian

$\mathrm{f}_{\mathrm{e}} \quad$ : Frekuensi yang diharapkan pada populasi penelitian

Tes signifikansi Chi kuadrat sebagai alat estimasi digunakan rumusan derajat kebebasan sebagai berikut :

$\mathrm{db}=\mathrm{k}-1$

keterangan :

$\mathrm{db} \quad$ : Derajat kebebasan

$\mathrm{k} \quad$ : Jumlah kategori

Untuk data $\mathrm{f}_{\mathrm{e}}$ dihasilkan dari :

Diketahui : luas lahan 56,50 Ha

Jarak tanam $3 \times 6,6 \mathrm{~m}$

Populasi 26.439 pohon

Klon RRIC 100
Tarjet produksi 25.099 liter

a. Vol. latek $=$ tarjet per bulan : jumlah populasi

$=25.099: 26439$

$=0,949$ liter $(949 \mathrm{Cc})$

Sistem sadap yang diterapkan pada tanaman karet klon RRIC 100 tahun tanam 2005 yaitu 1/2 S D3. Sehingga dalam 1 bulan terdapat 10 kali sadap. Jadi volume lateks yang dihasilkan per pohonnya adalah :

$$
\begin{aligned}
& =949: 10 \\
& =94,9 \text { Cc per pohon/sadap }
\end{aligned}
$$

b. Kadar Karet Kering (KKK)

Data yang diambil untuk KKK yaitu hasil perhitungan dari kadar karet basah dikali faktor pembagi. Nilai kadar karet basah yang dipakai yaitu nilai terkecil yang sering muncul pada saat penelitian. Dengan rumus perhitungan sebagai berikut :

KKK = Kadar karet basah X $75 \%$ (faktor pembagi, ketentuan dari kebun)

$$
\begin{aligned}
& =28 \times 75 \% \\
& =21 \%
\end{aligned}
$$

c. Produksi Kering

Produksi kering dihasilkan dari kadar karet kering per 100Cc dikali produksi basah:

$$
\text { Produksi kering }=\frac{21}{100} \times 94,9
$$

$\mathrm{Kg}$

Data hasil dianalisis dengan Chi kuadart. Jumlah tanaman yang diteliti sebanyak 316, dan masing masing perlakuan 158 tanaman.

Adapun dua perlakuan dalam penelitian ini yaitu :

P0: $\quad 158$ tanaman tanpa menggunakan stimulant ethrel $10 \mathrm{PA}$.

P1: $\quad 158$ tanaman dengan menggunakan stimulant ethrel 10 PA sebanyak 2 tetes/pohon.

\subsection{Tahapan Penelitian}

Ada beberapa tahapan-tahapan yang harus dilaksanakan dalam penelitian ini yaitu:

a. Scrap dibuka dengan pisau scrapper/sadap.

b. Getah yang dikeluarkan ditunggu sampai kering $\pm 0,5-1$ jam.

c. Alur sadap dibersihkan kembali dengan kain lap.

d. Oleskan stimulansia ethrel dengan pengeceran $1: 3$ ( 1 liter ethrel : 3 liter air) sebanyak 2 tetes kemudian diratakan.

e. Pengambilan data dilakukan dan dihitung setiap kali waktu penyadapan dilakukan.

f. Penyadapan dilakukan setiap 3 hari sekali, karena sistem yang dilakukan yaitu 1/2S D/3

\subsection{Pengamatan Penelitian}

a. Produksi lateks/ volume lateks (liter): Perhitungan dilakukan setiap kali penyadapan (3 hari sekali). 
b. Kadar Karet Kering (\%): Perhitungan dilakukan setiap kali penyadapan (3 hari sekali).

c. Produksi kering $(\mathrm{Kg})$ : Perhitungan dilakukan setiap kali penyadapan (3 hari sekali).

\section{HASIL DAN PEMBAHASAN} 3.1 Hasil

Hasil Analisis Chi Kuadrat pemberian stimulant pada tanaman karet klon RRIC 100 hasilnya disajikan pada Tabel 4.1, Tabel 4.2, dan Tabel 4.3

Tabel 3.1 Hasil Analisis Chi Kuadrat Produksi Lateks (ml) Tanaman Karet Klon RRIC 100

\begin{tabular}{llllll}
\hline $\begin{array}{l}\text { Apli } \\
\text { kasi }\end{array}$ & Kontrol & $\begin{array}{l}\text { Perla } \\
\text { kuan }\end{array}$ & X2 & $\begin{array}{l}\text { Chi } \\
\text { Tabel }\end{array}$ & $\begin{array}{l}\text { Nota } \\
\text { si }\end{array}$ \\
\hline 1 & 116,40 & $\begin{array}{l}211, \\
3\end{array}$ & 147,50 & 3,84 & $*$ \\
2 & 116,40 & $\begin{array}{l}199, \\
9\end{array}$ & 120,90 & 3,84 & $*$ \\
3 & 122,70 & $\begin{array}{l}9 \\
199,\end{array}$ & 124,20 & 3,84 & $*$ \\
& & 9 & & & \\
\hline
\end{tabular}

Keterangan : * Berbeda Nyata

Tabel 3.2 Hasil Analisis Chi Kuadrat Kadar Karet Kering (\%) Tanaman Karet Klon RRIC 100

\begin{tabular}{llllll}
\hline $\begin{array}{l}\text { Apli } \\
\text { kasi }\end{array}$ & Kontrol & Perlakuan & X2 & $\begin{array}{l}\text { Chi } \\
\text { Tabel }\end{array}$ & $\begin{array}{l}\text { Nota } \\
\text { si }\end{array}$ \\
\hline 1 & 23,08 & 23,10 & 0,41 & 3,84 & $\mathrm{~ns}$ \\
2 & 23,30 & 21,70 & 0,25 & 3,84 & $\mathrm{~ns}$ \\
3 & 22,30 & 22,90 & 0,26 & 3,84 & $\mathrm{~ns}$ \\
\hline \multicolumn{7}{l}{ Keterangan $:$ ns Tidak Berbeda Nyata }
\end{tabular}

Tabel 3.3 Hasil Anilisis Chi Kuadrat Produksi Kering (Kg) Tanaman Karet Klon RRIC 100

\begin{tabular}{llllll}
\hline $\begin{array}{l}\text { Apli } \\
\text { kasi }\end{array}$ & Kontrol & $\begin{array}{l}\text { Perlak } \\
\text { uan }\end{array}$ & X2 & $\begin{array}{l}\text { Chi } \\
\text { Tabel }\end{array}$ & Notasi \\
\hline 1 & 26,50 & 48,80 & $\begin{array}{l}44,0 \\
0\end{array}$ & 3,84 & $*$ \\
2 & 26,90 & 43,40 & $\begin{array}{l}30,1 \\
0\end{array}$ & 3,84 & $*$ \\
3 & 27,40 & 45,90 & $\begin{array}{l}36,7 \\
0\end{array}$ & 3,84 & $*$ \\
& & & &
\end{tabular}

\section{Keterangan :* Berbeda Nyata}

Analisis menggunakan uji Chi - Kuadrat seperti tercantum pada Tabel 4.1 dan Tabel 4.3, menunjukan hasil yang berbeda nyata. Hal ini menjelaskan bahwa pemberian stimulant pada tanaman karet berpengaruh baik pada produksi yang dihasilkan.

Sedangkan pada Tabel 4.2, menunjukkan hasil yang tidak berbeda nyata. Hal ini menjelaskan bahwa pemberian stimulant tidak memberikan pengaruh baik pada kadar karet kering.

\subsection{Pembahasan}

Penyadapan yang baik pada suatu areal pertanaman karet dapat diketahui dari mutu bidang sadap. Penyadapan dikatakan baik bila mana kriteria penyadapan dipenuhi oleh penyadap. Seluruh kriteria itu dapat diamati pada bidang sadap seperti konsumsi kulit, luka kayu yang terjadi, dan kebersihan mangkuk (Siregar, 1995).

Arah irisan sadap pada sadapan bawah adalah dari kiri atas ke kanan bawah, sedangkan pada sadapan arah atas adalah sebaliknya. Arah sadapan yang demikian, kecuali mudah pelaksanaannya juga arah pembuluh-pembuluh lateks itu sendiri berada pada kulit batang dan membentang agak miring dari kiri bawah ke kanan atas dengan membentuk sudut $3,7^{\circ}$ dari garis vertical. Dengan melaksanakan irisan sadapan dengan arah dari kiri atas ke kanan bawah pembuluh-pembuluh lateks akan terpotong dengan baik sehingga menghasilkan aliran getah/lateks yang deras dan banyak (Setyamidjaja, 1993).

Pemakaian kulit harus dilakukan dengan baik agar kontinuitas penyadapan dan kelangsungan hidup tanaman produktif terpelihara dengan baik. Jadi, penyadapan bukan hanya sekedar mengiris kulit untuk memperoleh lateks sebanyak-banyaknya dan secepat-cepatnya, melainkan harus dipertimbangkan pula kemampuan pohon untuk menghasilkan lateks (Setyamidjaja, 1993).

Pembuluh lateks terdapat pada sekeliling kayu, terutama bagian kayu dari batang. Jumlah pembuluh lateks pada kulit tersebut makin ke dalam sampai batas mendekati kambium makin besar jumlahnya. Oleh karena itu, sewaktu menyadap sayatan harus cukup dalam tetapi tidak sampai mengenai kambium. Adapun yang dimaksud dengan dalamnya sadapan adalah sisa kulit setelah irisan sadapan dilakukan diukur dari cambium. Penyadapan yang sampai melukai kambium akan merusak bidang sadap, karena pemulian bidang sadap terhambat (Setyamidjaja, 1993).

Turun naiknya tekanan turgor dipengaruhi oleh waktu (sepanjang hari), yang tentu saja berpengaruh terhadap pengaliran lateks. Tekanan turgor tertinggi adalah pada jam $4.00-8.30$ pagi. Pada saat itu penyadapan layak dilakukan untuk mendapatkan tetesan lateks yang banyak. Tetapi sejalan dengan waktu dan intensitas sinar matahari semakin tinggi, maka akan menyebabkan tekanan turgor semakin menurun, sehingga pengaliran lateks semakin sedikit. Fenomena ini akan semakin nyata bila diamati pengaliran lateks pada menit pertama setelah penyadapan di pagi hari.pada menit berikutnya, jarak waktu antara tetesan yang satu dengan tetesan yang lain akan semakin lambat dan berkombinasi dengan meningkatnya suhu lateks cenderung membeku di alur sadap (Siregar, 1995).

Peningkatan produksi disebabkan lama aliran lateks yang meningkat secara tajam setelah 
Danis Eko Prasetyo, Dian Hartatie dan Ujang Setyoko, Pengaruh Stimulansia Ethrel 10 PA Terhadap Produksi Lateks Tanaman Karet (Hevea brasilliensis) Pada Klon RRIC 100 Di Perkebunan Kalisanen

aplikasi stimulant. Hal tersebut dikarenakan senyawa etilen pada ethrel dapat menstabilkan tekanan osmotik lateks dan lutoid sehingga dapat menunda terjadinya koagulasi. Diperkuat pendapat dari Eva herlinawati dan kuswandi (2012), Lutoid merupakan fraksi dasar lateks yang banyak mengandung kation. Apabila lutoid pecah kation kation ini akan bereaksi dengan partikel karet yang bermuatan negative sehingga terjadi koagulasi. Menurut Nasaruddin dan Deasy Maulana. (2009), Gas etilen yang dihasilkan dari ethrel dapat menurunkan aktifitas enzim oksidase serta meningkatkan tekanan turgor dan kandungan pospor lateks. Oleh karena itu gas etilen dapat menunda penyumbatan pembuluh lateks dan memperlama masa aliran lateks

Selain itu jika kriteria dan syarat - syarat penyadapan sudah dilakukan dengan benar maka, produksi yang dihasilkan akan meningkat. Selain itu penggunaan stimulant ethrel 10PA akan membantu pengaliran lateks menjadi lebih lancar. Hal ini dikarenakan fungsi dari stimulant sendiri yaitu memperpanjang masa pengaliran lateks.

Stimulant ethrel 10PA tidak memberikan pengaruh pada kadar karet kering (KKK). Karena stimulant hanya memberikan pengaruh pada jumlah produksi. Besar kecilnya angka kadar karet kering (KKK) dapat dipengaruhi oleh kebersihan lateks yang dihasilkan. Angka kadar karet kering akan tinggi jika lateks yang dihasilkan bersih dari kotoran atau campura air. Jika pada lateks terdapat kotoran seperti tanah yang menepel pada mangkuk, kayu bekas irisan sadap dan campuran air, maka angka kadar karet kering akan kecil. Hal ini dapat dicegah jika penyadap memperhatikan syarat - syarat penyadapan seperti kebersihan mangkuk dan penyadap tidak melakukan kecurangan untuk menambahkan air pada lateks yang dihasilkan. Penyadap juga dapat melakukan pencucian mangkuk lateks setelah selesai melakukan pengambilan lateks (kolot) pada pohon karet yang disadapnya. Sehingga pada saat malakukan penyadapan selanjutnya, keadaan mangkuk lateks sudah bersih dari kotoran.

\section{KESIMPULAN DAN SARAN}

\subsection{Kesimpulan.}

Berdasarkan hasil dan pembahasan perlakuan stimulant terhadap hasil produksi lateks dapat disimpulkan bahwa perlakuan stimulant berpengaruh baik terhadap hasil produksi lateks tetapi tidak berpengaruh baik terhadap kadar karet basah dan kadar karet kering.

\subsection{Saran.}

Perlu dilakukan pengawasan lebih teliti ketika melakukan pengumpulan lateks di tempat pemungutan hasil guna menghindari kecurangan oleh penyadap sehingga bisa mendapatkan data yang lebih real terutama pada kadar karet basah dan kadar karet kering.

\section{DAFTAR PUSTAKA}

BPS, 2011. Peran Tanaman Karet Dalam Perekonomian Indonesia. Jakarta

Balai Penelitian Sungei Putih. 2007. Klon Karet Anjuran 2006 - 2010. Medan. 66 hal.

Eva Herlinawati dan Kuswandi. 2012. Pengaruh Stimulan Gas Terhadap Produksi dan karakter Fisiologi Klon BPM 24. Dalam Jurnal Penelitian Karet Vol 30 No.2. Halaman 100-107. Bogor: Pusat penelitian Karet Riset Perkebunan Nusantara.

Nasaruddin dan Deasy Maulana. 2009. Produksi Tanaman Karet Pada karet Pada Pemberian Stimulan Elephon. Dalam Jurnal Agrisistem Desember 2009, Vol. 5 No. 2 ISSN 1858-4330. Universitas Katolik Delasalle Menado

Setyamidjaja, D. 1993. Budidaya dan Pengolahan Karet. Jogjakarta: Kanisius

Siregar, T, HS. 1995. Teknik Penyadapan Karet. Jogjakarta: Kanisius

Soepeno, B. 1997. Statistika terapan dalam penelitian ilmu-ilmu sosial pendidikan. Jakarta: Rineka Cipta.

Syamsulbahri,1996. Bercocok Tanam Tanaman Perkebunan Tahuna, Yogyakarta: Gajah Mada Press. 